F. Reprod. Fert. (1971) 27, 5-11

\title{
HISTO-ENZYMOLOGICAL OBSERVATIONS ON SPERMATOZOA OF INBRED STRAINS OF MICE
}

\author{
R. S. MATHUR* \\ Department of Genetics, University of Edinburgh
}

(Received 26th May 1970, revised 31st March 1971)

\begin{abstract}
Summary. Enzymes have been located in the various parts of the spermatozoa of three inbred strains of mice, CBA, C57 and JBT, some enzymes giving very strong reactions. The acrosomal region contains glucose-6-phosphatase, ATPase and monoamine oxidase. The postnuclear cap appears to have only glucose-6-phosphatase whereas the head base shows reactivity for this and also for cholinesterase and monoamine oxidase. The bulk of the enzymes is located in the midpiece of the spermatozoon which not only contains all enzymes present in the other parts of the cell, but also gives positive reactions for various dehydrogenases, DOPA oxidase, $\beta$-glucuronidase and leucine aminopeptidase. The tail region differs from the midpiece in the absence of dehydrogenases and certain other enzymes. No significant variation has been observed in the activities of the enzymes between the different strains although in some instances minor differences are suspected.
\end{abstract}

\section{INTRODUGTION}

The localization of certain enzymes in the spermatozoa of mammals reported by several workers in the past has been reviewed by Mann (1964). Most of the investigators have studied primarily the spermatozoa of bull, ram or other higher mammals but very little information is available about the enzyme constitution of the spermatozoa of lower placentals, particularly rodents. The present studies are of enzyme localization in the spermatozoa of inbred mice, combined with an attempt to detect differences in enzyme activity between the strains.

\section{MATERIALS AND METHODS}

Mice used were from the inbred strains $\mathrm{CBA} / \mathrm{Fa}, \mathrm{C} 57 \mathrm{BL} / \mathrm{Fa}$ and JBT/Jd, maintained in the Department. The animals were killed by an overdose of ether. The spermatozoa were obtained by squeezing the excised vas deferens and were suspended in $0.85 \%$ saline. Thin smears were prepared for examining under phase contrast, or were stained with nigrosin-eosin (Beatty, 1957). All the enzyme reactions were carried out on the unfixed smear preparations, which were then photographed in a Zeiss Ultraphot with Optovar system using a Kodak

\footnotetext{
* Permanent address: Cell Biology Section, Department of Zoology, University of Rajasthan,
} Jaipur 4, India. 
Wratten dark green filter. The histochemical techniques employed for the localization of the various enzymes are listed below. With each method, appropriate control slides were prepared as specified for the technique.

\section{Enzyme}

Alkaline phosphatase

Glucose-6-phosphatase

Adenosinetriphosphatase

5'-Nucleotidase

Acid phosphatase

Lipase

Esterase

Cholinesterase

$\beta$-Glucuronidase

$\alpha$-Glucosidase

$\beta$-Galactosidase

Peroxidase

DOPA oxidase

Monoamine oxidase

TPN diaphorase

DPN diaphorase

Succinic dehydrogenase

Malate dehydrogenase

Isocitric dehydrogenase

Lactate dehydrogenase

6-Phosphogluconate dehydrogenase

Leucine aminopeptidase
Method

Coupling azo-dye method

Lead method

Lead method

Modified lead nitrate method

Tween method

Indoxyl acetate method

Acetylthiocholine method

Post-coupling method

Post-coupling method

Post-coupling method

Benzidine method

(a) Block-Peck method

(b) Without silver

Tetrazolium method

Nitro BT method

Nitro BT method

(a) Using Nitro BT

(b) Modified Nitro BT method

(c) Neotetrazolium method

(d) Using MTT

DPN and Nitro BT

DPN and Nitro BT

DPN and Nitro BT

TPN and MTT

Using L-leucyl-4-methoxyl- $\beta$ napthylamide
Reference

Pearse (1960)

Wachstein \& Meisel (1956)

Wachstein \& Meisel (1957)

Pearse (1960)

Takeuchi \& Tanoue (1951)

Gomori (1953)

Holt (1958)

Gomori (1953)

Seligman et al. (1954)

Rutenburg et al. (1958a)

Rutenburg et al. (1958b)

van Duijn (1955)

Lillie (1954); Becker

et al., quoted by Pearse

(1960)

Glenner et al. (1957)

Nachlas et al. (1958a)

Nachlas et al. (1958b)

Nachlas et al. (1957b)

Burstone (1962)

Rosa \& Velardo (1954)

Pearse (1960)

Hess et al. (1958)

Hess et al. (1958)

Hess et al. (1958)

Hess et al. (1958)

Nachlas et al. (1957a)

\section{RESULTS}

The morphological characteristics of the spermatozoa of the strains of CBA and C57 have been described by Braden (1959) and Beatty \& Sharma (1960). The JBT spermatozoon is unusual in several ways (Williams, Beatty \& Burgoyne, 1970) and has a long tapering acrosome (Beatty, personal communication). Morphology is illustrated in P1. 1, Figs. 1 to 3.

\section{Phosphatases}

Of the different phosphatases studied, alkaline phosphatase and 5'-nucleotidase gave negative results in all parts of the spermatozoa. The reaction for acid

\section{EXPLANATION OF PLATE 1}

FIgs. 1 to 3. Spermatozoa of CBA, C57 and JBT strains of mice. Nigrosin-eosin staining. $\times 1750$.

FIG. 4. Spermatozoa of JBT strain, showing glucose-6-phosphatase activity in the acrosomal tip (A), head base (B), midpiece $(M)$ and the tail. $\times 2100$.

FIG. 5. Spermatozoa of CBA mouse. ATPase reactivity is revealed in the acrosomal tip, (A), midpiece and the tail after $1 \mathrm{hr}$ incubation. $\times 2100$.

FIG, 6. Non-specific esterase activity in the spermatozoa of $\mathrm{C} 57$ mouse. Note the reaction in the midpiece. $\times 1260$.

Frg. 7. DOPA oxidase in CBA spermatozoa, showing uniform staining of the midpiece and the tail. Incubation in DOPA for $1 \mathrm{hr}$ with post-incubation treatment in silver nitrate. $\times 2130$.

Fig. 8. DOPA oxidase, silver technique. Note the strong reaction in the midpiece (M) as compared to the tail $(T) . \times 2130$. 
PI.ATE 1
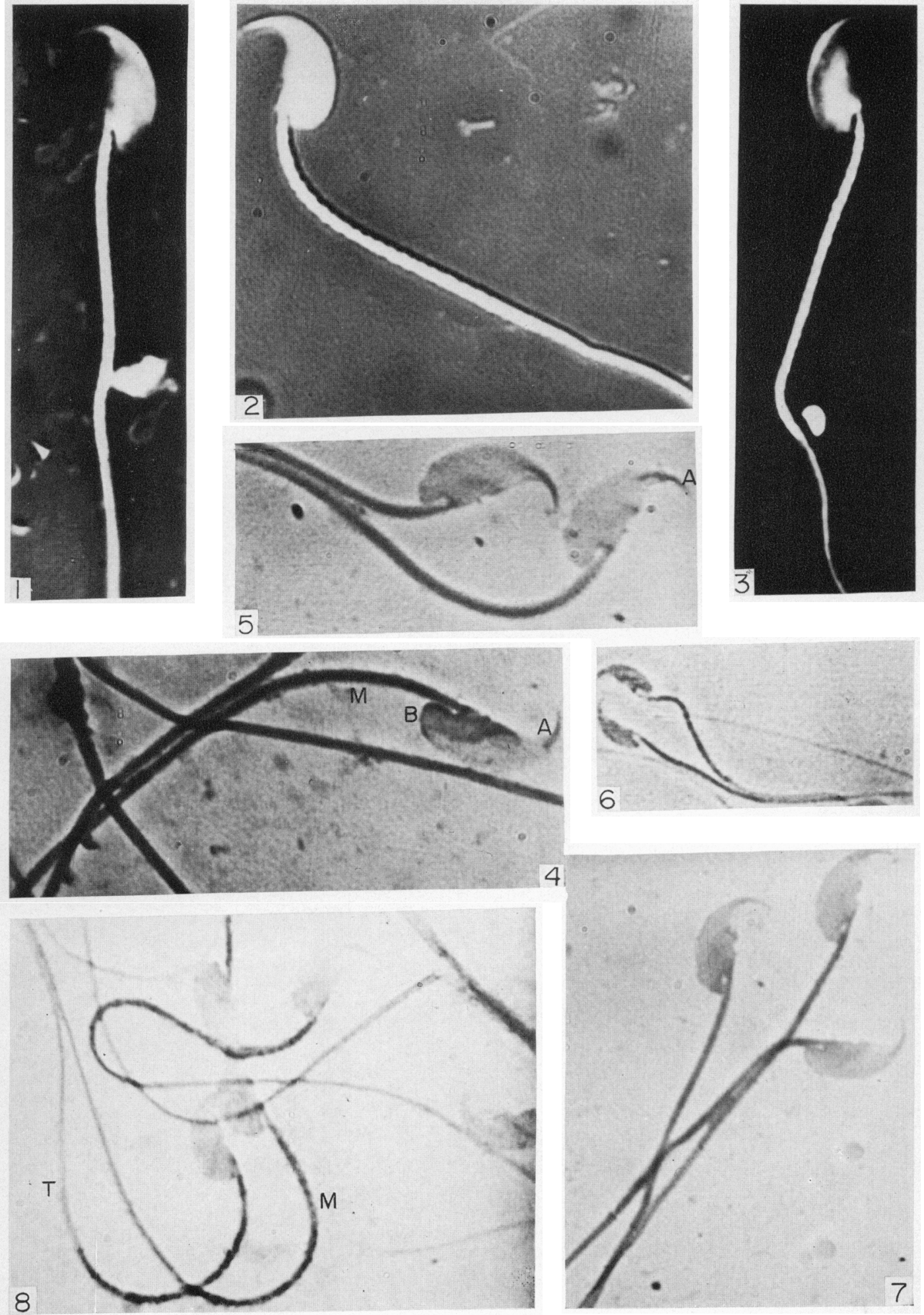
PLATE 2
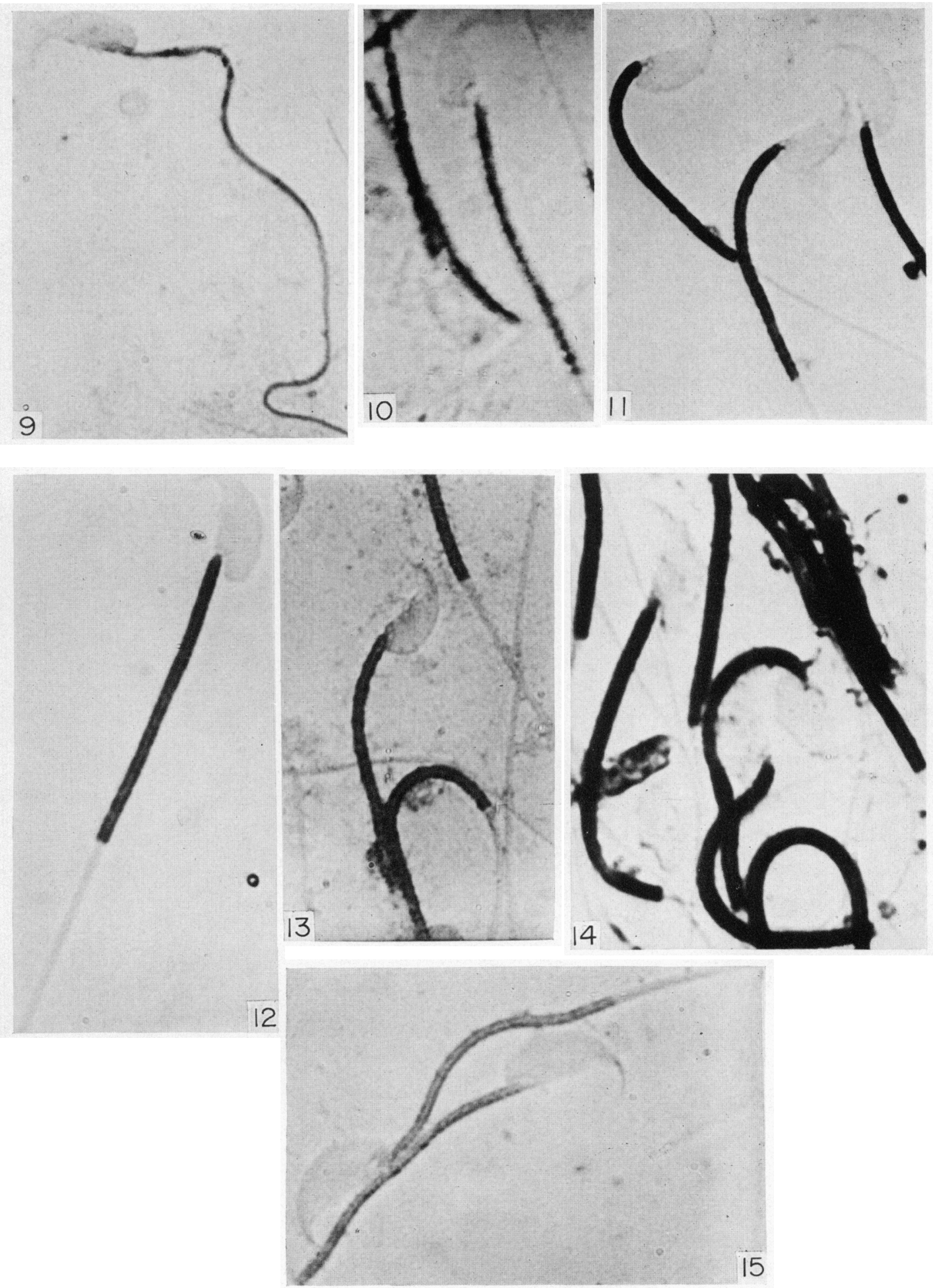

(Facing p. 7) 
phosphatase was very weak and it was difficult to judge the specificity in the different regions when compared with the controls. Glucose-6-phosphatase (G-6-Pase) and adenosinetriphosphatase (ATPase), however, had very specific localizations. The former was present in the acrosomal tip, the head base, the midpiece and the tail. In the postnuclear cap, the enzyme appeared to be less reactive in CBA and G57 than in JBT mice (Pl. 1, Fig. 4). The nuclei, in all preparations, were negative. ATPase, on the other hand, was chiefly confined to the acrosomal tip, the midpiece and the tail (Pl. 1, Fig. 5). The enzyme activity seemed to be the same in all strains. The best localization was achieved after $1 \mathrm{hr}$ of incubation although the enzyme could be detected even after a 10-min incubation.

\section{Esterases}

Non-specific esterase reactivity seemed to be confined to the midpiece (Pl. 1, Fig. 6) with a faint background staining of the nuclei and the tails. Amongst the specific esterases, lipase was absent but cholinesterase was present in the midpiece and the head base without any variation in specificity between the different strains.

\section{Oxidases}

The acrosomal tip, head base and flagellum reacted positively for monoamine oxidase (MAO). The reactivity in the first two structures was lower than in the flagellum. The intensity of the reaction gradually diminished towards the posterior part of the tail. Again, this enzyme did not exhibit any variation in the different strains.

The silver and non-silver methods for the identification of DOPA oxidase gave the same results. The enzyme was localized in the same parts of the spermatozoa of the different strains, but there was a possible difference in degree. In CBA-strain mice, the midpiece and the tail appeared to have the same reactivity ( $\mathrm{Pl}$. 1, Fig. 7) while $\mathrm{C} 57$ spermatozoa revealed a strongly positive midpiece and a weakly active tail (Pl. 1, Fig. 8). In JBT spermatozoa, however, the reaction was of a lighter intensity without any apparent difference between the midpiece and the tail (Pl. 2, Fig. 9). The benzidine method for peroxidase

\section{EXPLANATION OF PLATE 2}

FIG. 9. JBT spermatozoa, showing a weak reaction for DOPA oxidase. The midpiece and the tail do not indicate any difference in reactivity. $\times 2130$.

FIG. 10. CBA spermatozoa, showing strongly positive reaction in the midpiece for SDH as revealed by the Nitro BT technique. $\times 2130$.

FIG. 11. Intense IDH localization in the midpiece of CBA spermatozoa with Nitro BT technique. $\times 2130$.

FIG. 12. DPN diaphorase localization in the midpiece of JBT spermatozoa. Nitro BT technique. $\times 2240$.

F1G. 13. C57 spermatozoa showing the intra-mitochondrial deposits of MDH. Nitro BT technique, $\times 2130$.

FIG. 14. LDH localization in CBA spermatozoa. Note the characteristic strong reaction in the midpiece and a weak reaction in the tail. Nitro BT technique. $\times 2800$.

FIg. 15. CBA spermatozoa showing 6-phosphogluconate dehydrogenase activity. Nitro BT technique. $\times 2800$. 
repeatedly gave a distorted appearance to the spermatozoa and it was, therefore, very difficult to interpret the preparations.

\section{Glycosidases}

No differences or variation in the intensities of the reactions in the enzymes of this group were noticed in the different strains. Both $\alpha$-glucosidase and $\beta$ galactosidase were absent in the spermatozoa and only $\beta$-glucuronidase appeared to be positive in the midpiece.

\section{Proteolytic enzyme}

The only enzyme investigated from this group was leucine aminopeptidase which gave a faint reaction in the flagellum and did not show any strain variation.

\section{Dehydrogenases}

Of the various tetrazolium compounds used for the identification of the dehydrogenases, Nitro BT and MTT gave the most satisfactory results. Succinic dehydrogenase (SDH), isocitric dehydrogenase (IDH), DPN diaphorase, malic dehydrogenase $(\mathrm{MDH})$, lactic dehydrogenase $(\mathrm{LDH})$ and 6-phosphogluconate dehydrogenase, all gave very specific and characteristic localization in the midpiece as deposits associated with the mitochondria (Pl. 2, Figs. 10 to 15). There was, in general, no variation in the reactivity of the various dehydrogenases in the different strains although LDH gave an intense reaction in CBA spermatozoa as compared to C.57 and JBT spermatozoa, and LDH and 6-phosphogluconate dehydrogenase were the only two enzymes of this group which appeared to show some reactivity in the tail region. Finally, TPN diaphorase, using both Nitro BT and MTT, failed to give any positive reaction.

\section{DISCUSSION}

The present study deals with the identification and the distribution of the enzymes in the spermatozoa of different inbred strains of mice. Although the general pattern of enzyme constitution is similar in the spermatozoa of different strains, some possible variations have been observed, and these are now being studied by direct chemical determinations. Most of the enzymes studied have not been reported and a comprehensive account of their distribution in the spermatozoa of mice or any related species is lacking.

Wislocki (1950) has reported the presence of acid and alkaline phosphatases in human spermatozoa, the former being located in the sperm head in the 'equatorial segment', galea capitis, middle and tail pieces of spermatozoa, while the latter is present in the region of the junction of the head and the neck. Recent studies of Allison \& Hartree (1970), in different vertebrate spermatozoa, have revealed the presence of acid phosphatase in the acrosome. In the present investigations, spermatozoa from different strains exhibited a total absence of alkaline phosphatase and a very weak or unspecific reaction for acid phosphatase. In bull spermatozoa, Mann (1964) did observe positive acid phosphatase activity in the galea capitis but concluded that phosphatase activity, acid and alkaline alike, may be due to possible contamination by seminal plasma 
phosphatases and not to phosphatases originally present in the spermatozoa. In the present work with spermatozoa from the vas deferens, there was no seminal plasma and, on Mann's theory, this would explain the negative or near negative reactions. Further, the absence of $5^{\prime}$-nucleotidase, which is present in the seminal plasma (Mann, 1964), supports the above view. Glucose-6phosphatase, on the other hand, which has not been reported earlier in mammalian spermatozoa, preferentially hydrolyses glucose-6-phosphate and is recognized by specific transferase activity in contrast to non-specific phosphatases. The $\mathrm{pH}$ optimum for this enzyme is 6.7 as contrasted to 5.0 for acid phosphatase and $9 \cdot 4$ for alkaline phosphatase, and the enzyme can therefore easily be distinguished (Burstone, 1962). The enzyme has a specific distribution in the acrosomal tip, postnuclear cap, head base, midpiece and the tail of all the different strains. The presence of ATPase has been reported in the midpiece and the tail of several mammalian spermatozoa (see Mann, 1964). Recently, Quinn \& White (1968) have given support to the earlier findings in ram and bull spermatozoa and have also observed low activity in the head region. The present observations also identify the enzyme in the midpiece and the tail, and its presence in the tip of the acrosome may correspond to the zone of low activity in the head region observed by Quinn \& White (1968).

The non-specific esterase activity is chiefly confined to the midpiece in mouse spermatozoa. This is supported by the finding that cholinesterase activity is confined to this region, and extends up to the head base. It is, therefore, very likely that the activity may be due to this enzyme since the other specific esterase, lipase, is absent. Mann (1964), in tail fragments of ram sperm homogenates, and Nelson (1964), in the head, midpiece and the tail of bull spermatozoa, have reported cholinesterase activity. The present results agree with those of Nelson about localization in the midpiece, but mouse spermatozoa do not show any reactivity in the head and the tail regions.

Monoamine oxidase is an insoluble and relatively stable enzyme and possibly related to the inactivation in vivo of adrenalin (Burstone, 1962). This enzyme has not been reported in the spermatozoa by earlier workers. The present studies have indicated its presence in the acrosomal tip, head base, midpiece and the proximal part of the tail. It is possible that the spermatozoa may be the source of this enzyme for the oxidation of adrenalin since the seminal plasma is devoid of the enzyme (Zeller \& Joel, 1941). Deoxyphenylalanine oxidase is associated with the melanizing activity. Beatty (1956) had found a variability in staining in the spermatozoa of different strains of rabbits, where the reaction seemed to depend on the coat colour (but see Beatty, 1970). In the mice, the midpiece and the tail are positive but with unequal reactivity. It has been reported by Mann (1964) that both spermatozoa and the epididymal secretions contain active glycosidases, particularly $\alpha$-mannosidase and $\beta$ - $\mathrm{N}$-acetylglucosaminidase. In mouse spermatozoa, amongst the glycosidases investigated, only $\beta$-glucuronidase is present in the midpiece, where it shows moderate activity; $\alpha$-glucosidase and $\beta$-galactosidase are absent. This is also true for leucine aminopeptidase which is present in small quantities in the midpiece and the tail. In both enzymes, weak activity does not indicate any specific function and there is a difficulty in judging their rôle in metabolism. 
Nelson (1959) in rat, and several other authors (see Mann, 1964), have claimed that SDH in spermatozoa is mainly associated with the flagellum and is present in higher concentration in the midpiece than the tail, whereas Edwards \& Valentine (1963), in rabbit spermatozoa, have reported the presence of SDH only in the midpiece. The present observations support this view in mouse spermatozoa. Smith, Mayer \& Merilan (1956) have identified MDH in bull spermatozoa. In mouse spermatozoa, the entire dehydrogenase system is very specific to the midpiece and is intra-mitochondrial. The only exceptions are LDH and 6-phosphogluconate dehydrogenase which show traces of activity in the tail, and TPN diaphorase, which is completely absent. It may, therefore, be summed up that virtually the entire dehydrogenase activity is governed by the midpiece in mouse spermatozoa, and in spite of the absence or variation in reactivity of the enzymes of this group in certain strains the spermatozoa remain fertile.

The specificity of the more weakly-reacting enzymes is being checked by direct chemical determinations that will be reported elsewhere. The histochemical observations alone already give clear evidence of the presence of G-6-Pase, ATPase, DOPA oxidase and dehydrogenases.

\section{AGKNOWLEDGMENTS}

I wish to record my grateful thanks to Dr R. A. Beatty for his keen interest and helpful criticism during the present investigations. My thanks are also due to the University of Edinburgh for a Senior Research Fellowship, made possible by a Ford Foundation Grant in support of research by Dr R. A. Beatty; to the Commonwealth Foundation, London for a travel grant; and to the University of Rajasthan, Jaipur, India, for granting me study leave. I am grateful to Professor D. S. Falconer for the hospitality of the Department of Genetics.

\section{REFERENCES}

Allison, A. G. \& HaRTRee, E. F. (1970) Lysosomal enzymes in the acrosomes and their possible rôle in fertilization. F. Reprod. Fert. 21, 501 .

Beatty, R. A. (1956) Melanizing activity of semen from rabbit males of different genotype. Proc. $R$. phys. Soc. Edinb. 25, 39.

Beatty, R. A. (1957) Nigrosin-eosin staining of rabbit spermatozoa and the fertility of semen. Proc. R. Soc. Edinb. B, 67, 1.

BeAtTY, R. A. (1970) The genetics of the mammalian gamete. Biol. Rev. 45, 73.

BeatTy, R. A. \& Sharma, K. N. (1960) Genetics of gametes. III. Strain differences in spermatozoa from eight inbred strains of mice. Proc. R. Soc. Edinb. B, 68, 25.

Braden, A. W. H. (1959) Strain differences in the morphology of the gametes of the mouse. Aust. $\mathcal{F}$. biol. Sci. 12, 65 .

Burstone, M. S. (1962) Enzyme histochemistry and its application in the study of neoplasms. Academic Press, New York.

Edwards, R. G. \& VALEnTiNe, R. C. (1963) Cytochemical demonstration of succinic dehydrogenase in intact rabbit spermatozoa. Expl Cell Res. 31, 508.

Glenner, G. G., Burtner, H. J. \& Brown, G. W., JR (1957) The histochemical demonstration of monoamine oxidase activity by tetrazolium salts. $\mathcal{F}$. Histochem. Cytochem. 5,591 .

Gomori, G. (1953) Microscopic histochemistry. Chicago University Press.

Hess, R., Scarpel.l, D. G. \& Pearse, A. G. E. (1958) Cytochemical localization of pyridine nucleotidelinked dehydrogenases. Nature, Lond. 181, 1531.

HoLt, S. J. (1958) In: General cytochemical methods, vol. 1, p. 375. Ed. J. F. Danielli. Academic Press, New York.

LrLLIE, R. D. (1954) Histopathologic technic and practical histochemistry, p. 230. Blakiston, New York.

MANN, T. (1964) The biochemistry of semen and of the male reproductive tract. Methuen, London. 
Nachlas, M. M., Grawford, D. T. \& Seligman, A. M. (1957a) The histochemical demonstration of leucine aminopeptidase. 7. Histochem. Cytochem. 5, 264.

Nachlas, M. M., Tsou, K. C., De Souza, E., Cheng, C. S. \& Seligman, A. M. (1957b) Cytochemical demonstration of succinic dehydrogenase by use of a new $p$-nitrophenyl substituted ditetrazole. 7. Histochem. Cytochem. 5, 420.

Nachlas, M. M., Walker, D. G. \& Seligman, A. M. (1958a) The histochemical localization of triphosphopyridine nucleotide diaphorase. . biophys. biochem. Cytol. 4, 467.

Nachlas, M. M., Walker, D. G. \& Seligman, A. M. (1958b) A histochemical method for the demonstration of diphosphopyridine nucleotide diaphorase. J. biophys. biochem. Cytol. 4, 29.

Nelson, L. (1959) Cytochemical studies with the electron microscope. II. Succinic dehydrogenase in rat spermatozoa. Expl Cell Res. 16, 403.

NeLson, L. (1964) Acetylcholinesterase in bull spermatozoa. 7. Reprod. Fert. 7, 65.

PeArse, A. G. E. (1960) Histochemistry, theoretical and applied. Churchill, London.

QuIN, , P. J. \& WhITE, I. G. (1968) Distribution of adenosinetriphosphatase activity in ram and bull spermatozoa. F. Reprod. Fert. 15, 449.

Rosa, G. G. \& VelaRdo, J. T. (1954) Histochemical demonstration of succinic dehydrogenase activity in tissue sections by a modified technique. 7 . Histochem. Cytochem. 2, 110.

Rutenburg, A. M., Lang, R., Goldburg, J. A. \& Rutenburg, S. H. (1958a) A new method for the histochemical demonstration of $\alpha$-glucosidase. 7. Histochem. Cytochem. 6, 396.

Rutenburg, A. M., Rutenburg, S. H., Monis, B., Teague, R. \& Seligman, A. M. (1958b) Histochemical demonstration of $\beta$-D-galactosidase in the rat. 7. Histochem. Cytochem. 6, 122.

Seligman, A. M., Tsou, K. G., Rutengurg, S. H. \& Cohn, R. B. (1954) Histochemical demonstration of $\beta$-D-glucuronidase with a synthetic substrate. F. Histochem. Cytochem. 2, 209.

Smith, J. T., Mayer, D. T. \& Merilan, G. P. (1956) The effect of egg yolk and its isolated constituents upon the dehydrogenase activity of bovine spermatozoa. 7. Dairy Sci. 39, 552.

TAKeuchi, I. \& TANOUE, M. (1951) On the specificity of a histochemical demonstration of acid phosphatase and a new "Ammonia-Silver Method". Kumamoto med. 7. 4, 41.

van Duijn, P. (1955) An improved histochemical benzidine-blue peroxide method and a note on the composition of the blue reaction product. Red Trav. chim. Pays-Bas Belg. 74, 771.

Wachstern, M. \& MEISEL, F. (1956) On histochemical demonstration of glucose-6-phosphatase. 7. Histochem. Cytochem. 4, 592.

WACHSTEIN, M. \& MEISEL, F. (1957) Histochemistry of hepatic phosphatases at physiologic pH with special reference to the demonstration of bile canaliculi. Am. F. clin. Path. 27, 13.

Williams, D. A., BeAtTy, R. A. \& Burgoyne, P. S. (1970) Multivariate analysis in the genetics of spermatozoan dimensions in mice. Proc. $R$. Soc. B, 175, 313.

Wislocki, G. B. (1950) Cytochemical reactions of human spermatozoa and seminal plasma. Anat. Rec. 108, 645 .

ZeLler, E. A. \& JoEL, C. A. (1941) Uber das Vorkommen der Cholinesterase, der Mono-und-Diaminoxydase in Sperma und Prostata, und über die Beeinflussung der spermien Beweglichkeit durch Fermentinhibitoren. Helv. chim. Acta, 24, 968. 